University of Nebraska - Lincoln

DigitalCommons@University of Nebraska - Lincoln

$1-4-2008$

\title{
Rarity of Males in Pea Aphids Results in Mutational Decay
}

Jennifer A. Brisson

University of Nebraska-Lincoln, jennifer.brisson@rochester.edu

Sergey V. Nuzhdin

University of Southern California, Los Angeles, snuzhdin@usc.edu

Follow this and additional works at: https://digitalcommons.unl.edu/bioscifacpub

Part of the Life Sciences Commons

Brisson, Jennifer A. and Nuzhdin, Sergey V., "Rarity of Males in Pea Aphids Results in Mutational Decay" (2008). Faculty Publications in the Biological Sciences. 40.

https://digitalcommons.unl.edu/bioscifacpub/40

This Article is brought to you for free and open access by the Papers in the Biological Sciences at DigitalCommons@University of Nebraska - Lincoln. It has been accepted for inclusion in Faculty Publications in the Biological Sciences by an authorized administrator of DigitalCommons@University of Nebraska - Lincoln. 
Published in Science (January 4, 2008) v. 319: 58. Copyright 2008, American Association for the Advancement of Science. doi: 10.1126/science.1147919. Used by permssion.

\section{BREVIA}

\section{Rarity of Males in Pea Aphids Results in Mutational Decay Jennifer A. Brisson (jbrisson2@unl.edu) and Sergey V. Nuzhdin†}

The pea aphid, Acyrthosiphon pisum, has a complex life cycle that alternates seasonally between asexual and sexual reproduction(1). During the spring and summer months, $A$. pisum reproduces parthenogenetically, producing clonal daughters for 10 to 20 generations. Fall temperatures and photoperiods induce the production of sexual females and males (2), which mate to produce overwintering eggs that hatch into asexual females [Supporting Online Material (SOM) text].

Asexual females dominate the life cycle because of their short generation time, high fecundity, and longer seasonal presence. We hypothesized that males experience relaxed selection, resulting in accelerated evolution of male-biased genes relative to asexual female-biased genes.

In a previous study, whole-body asexual female and male RNA was hybridized on an A. pisum cDNA microarray representing $\sim 10 \%$ of the genome (1,734 unique genes) (3). We identified significantly different transcript accumulation between sexes via $t$ test with a false discovery rate $(F D R)<$ 0.05 and at least a twofold change in expression, yielding 107 asexual female-biased, 127 male-biased, and 95 sex-neutral genes (SOM text).

We identified orthologs of $A$. pisum genes in Genbank from the green peach aphid, Myzus persicae [in the same tribe as A. pisum (Macrosiphini)], and the cotton-melon aphid, Aphis gossypii [in the same subfamily but a different tribe (Aphidini)] (4). When comparing $A$. pisum and M. persicae orthologs, we found no differences between asexual female-biased and neutral nonsynonymous $\left(K_{a}\right)$ and synonymous $\left(K_{s}\right)$ rates of evolution, nor between their ratios $\left(K_{a} / K_{s}\right)$.

A
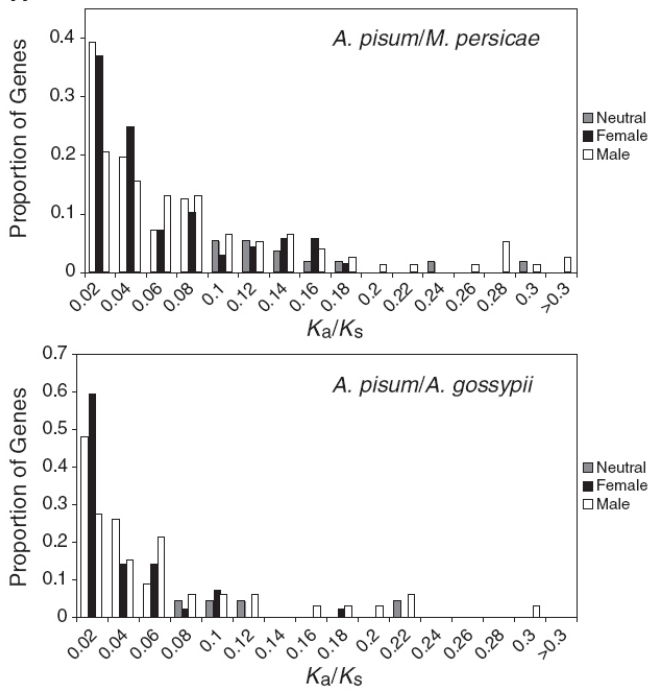

To distinguish between relaxed and positive selection, we sequenced 14 female- and 13 male-biased genes from 12 geographically disparate A. pisum clones and noted nonsynonymous and synonymous changes (table S2, averaging 10 individuals per locus). Despite low coding region diversity, we found significantly more nonsynonymous changes in male-biased genes (five versus zero; Fisher's exact test, $P=0.05$ ). We also observed an excess of nonsynonymous changes in male-biased genes between A. pisum and M. persicae homologs $(P<0.001$, table S3) consistent with the $K_{a} / K_{s}$ comparisons, and the numbers of nonsynonymous changes were consistent between interspecific and intraspecific data sets $(P=0.30$ and 0.26 for asexual female-biased and male-biased genes, respectively). The excess of nonsynonymous coding changes and consistency between interspecific and intraspecific patterns support relaxed, rather than positive, selection on male-biased genes in A. pisum.

Our data show that the dominance of the life cycle by parthenogenetic females can result in the mutational decay of male-biased genes. Whereas asexual female-biased genes are under constant selection, malebiased genes experience selection at most once per year (SOM text). Sexual selection may further reduce the effective population size of males, resulting in the fixation of weakly deleterious mutations (7). If relaxed selection alone is sufficient to produce accelerated male-biased gene evolution, we predict a similar pattern of decay in sexual female-biased genes. We conclude that the variation in genes related to males and asexual females are different in species combining sexual and asexual reproduction. These findings suggest new prospects for the role of sexual versus asexual reproduction in the adaptability of species to various environmental conditions.

References and Notes

1. N. A. Moran, Annu. Rev. Entomol. 37, 321 (1992).

2. S. Via, Entomol. Exp. Appl. 65, 119 (1992).

3. J. A. Brisson, G. K. Davis, D. L. Stern, Evol. Dev. 9, 338 (2007).

4. C. D. Von Dohlen, C. A. Rowe, O. E. Heie, Mol. Phylogenet. Evol. 38, 316 (2006).

5. S. Subramanian, S. Kumar, Genetics 168, 373 (2004).

6. A. Civetta, R. S. Singh, Genome 42, 1033 (1999).

7. W. G. Hill, A. Robertson, Genet. Res. 8, 269 (1966).

8. J.A.B. is supported by an National Research Service Award postdoctoral fellowship from the NIH, and S.V.N. is supported by NSF and NIH. Thanks to G. Davis and D. Stern for sharing unpublished data, P. Hui for laboratory assistance, and C. Braendle and T. Leonardo for aphid samples.

Fig. 1. (A) Distribution of $K_{\mathrm{a}} / K_{\mathrm{s}}$ values for each class of gene and each species comparison. (B) Evolutionary rates for genes with sex-biased or sex-neutral expression in comparisons of $A$. pisum to $M$. persicae and $A$. gossypii.
Supporting Online Material

http:// www.sciencemag.org/cgi/content/ full/319/5859/58/DC1

Materials and Methods, SOM Text, Tables S1 to S8, References

July 17, 2007; accepted October 23, 2007

Section of Ecology and Evolution, University of California, Davis, CA 95616, USA. 